\title{
The Influence of Covid-19 on the Power Transition between the United States and China: The Case of Southeast Asia*
}

\author{
Niall Duggan and Marcin Grabowski
}

University College Cork; Jagiellonian University, Krakow

\begin{abstract}
The Covid-19 pandemic is currently analysed as a social and economic problem, predominantly at a national level, even though certain activities are coordinated at an international or supranational level. While there are varying levels of vulnerability in different countries, the pandemic is having a significant effect on the global system's relative distribution of power, which will change in the aftermath of the pandemic and the resulting economic crisis. This problem is especially visible in relations between the current leader of the international system - the United States - and its main challenger, the People's Republic of China. The chief goal of this paper is to analyse Covid-19's influence on the transformation of the global system, with a special focus on the roles of the US and China. The impact of the CovID-19 pandemic on the relative distribution of power between the US and China will be analysed. The analysis will be based on the power transition theory. A single case study of Southeast Asia is used to study the impact of CoviD-19 on the power distribution between China and the US.
\end{abstract}

\footnotetext{
*This paper was originally presented at the annual conference of the International Affairs Standing Committee of the Royal Irish Academy, titled 'International politics in times of risk and uncertainty: the Covid-19 crisis and beyond', which took place on Thursday, 29 April 2021.
}

Author's e-mail: n.duggan@ucc.ie

Irish Studies in International Affairs, Vol. 32, No. 1 (2021), 1-20. (C) 2021 The Author(s)

doi: https://doi.org/10.3318/ISIA.2021.32.16

This is an open access article under the terms of the Creative Commons attribution license, which permits use, distribution and reproduction in any medium, provided the original work is properly cited. Open Access funding provided by IReL. 


\section{INTRODUCTION}

Since the signing of the Shanghai Communiqué (1972), the relationship between the People's Republic of China (China) and the US has developed contradictory paths. The two nations have become strategic partners and strategic rivals. China's post-1978 economic development led to the concept of China as a strategic rival or a growing 'threat' to the US, a threat that has increased during the post-Cold War era. ${ }^{1}$ However, the concept of the China threat has been discussed in the US in abstract terms as an issue that may occur at some point in the future rather than as a contemporary issue. In 2015, David M. Lampton argued that the rise of China had brought US-China relations to a tipping point, and that China could now be considered a strategic rival rather than a strategic partner. ${ }^{2}$ However, even Lampton's argument addressed the threat of China as an abstract future problem. Yet the Covid-19 pandemic has brought that abstract threat into reality. In a 2021 interview on the global response to the Covid-19 pandemic, President Joe Biden stated that 'We're kind of at a place where the rest of the world is beginning to look to China. ${ }^{33}$ Biden based this assessment on a comment the Irish taoiseach made. Micheál Martin stated: 'Well, America can't lead. They can't even get their arms around Covid. ${ }^{4}$ This suggests that the failure of the Trump administration to take the global lead on dealing with the CoviD-19 pandemic has reduced the US's standing in global politics.

While different countries are experiencing different levels of vulnerability, the Covid-19 pandemic has had a significant effect, at least during the period of the pandemic, on the relative distribution of power within the global system. This problem is especially visible in relations between the current leader of the international system - namely, the US - and its principal challenger, China. Several studies have suggested that the CoviD-19 pandemic has not had any significant impact on the long-term trajectory of the power balance between the US and China. ${ }^{5}$ The long-term impact of CoviD-19 cannot be fully assessed at this point as only short data series are available for analysis. At the same time, the long-term ramifications of the pandemic (inflation, problems in manufacturing value-added chains, and so on) have become more visible, with rising expectations of an imminent economic crisis due to the protracted pandemic. Those effects are less visible in China, due to a centralised, strict response to the

\footnotetext{
${ }^{1}$ Chengxin Pan, "The "China threat" in American self-imagination: the discursive construction of other as power politics', Alternatives: Global, Local, Political 29 (3) (2004), 305-31.

${ }^{2}$ David M. Lampton, 'The tipping point - can we amplify what we have in common?', Horizons: Journal of International Relations and Sustainable Development 4 (2015), 42-53.

${ }^{3}$ David Brooks, 'Has Biden changed? He tells us', New York Times, 20 May 2021.

${ }^{4}$ Brooks, 'Has Biden changed?'

${ }^{5}$ Nansheng Yuan, 'Reflections on China-US relations after the COVID-19 pandemic', China International Strategy Review 2 (1) (2020), 14-23; Daniel Drezner, 'The song remains the same: international relations after COVID-19', International Organization 74 (S1) (2020), E18-E35; Zhaohui Wang and Zhiqiang Sun, 'From globalization to regionalization: the United States, China, and the post-Covid-19 world economic order', Journal of Chinese Political Science 26 (1) (2021), 69-87.
} 
pandemic. In the longer run, however, more centralised, complex systems are less efficient in dealing with deferred effects of crises due to limited flexibility and limited bottom-up self-learning mechanisms. Thus, the positive relative effects of Covid-19 on China's position in the global system may not be sustainable. ${ }^{6}$ If Covid-19 will have no long-term impact on the Sino-US power balance, then why did President Biden perceive a reduction in the US's standing compared to China? Has the US's power reduced relative to China's in international affairs due to Covid-19?

The main goal of this article is to analyse the influence of the Covid-19 pandemic on the transformation of the global system, with a special focus on the US and China. The CoviD-19 pandemic will be understood as an external shock to both the US and China. The paper will use a single most-likely case study of US-China rivalry in Southeast Asia. The article will test the following hypotheses:

- Hypothesis 1: Covid-19 accelerated China's rise to power, causing a decline in the US's relative position in Southeast Asia.

- Hypothesis 2: Covid-19 has not affected the US's dominant regional position, which is based on relative capabilities, regulatory position and middle powers' allegiance.

The analysis will be based on Organski and Kugler's power transition theory and will consider three areas of leadership in the system - the relative distribution of power, the role of China and the US in international organisations, and the cooperation/allegiance of other countries, with a focus on middle powers, towards the US and China- and the influence of CovID-19 on those areas of leadership.

This article predominantly refers to realist paradigms in international relations, with a special focus on the power transition theory. Its methodological framework applies a document analysis (predominantly crucial strategic documents of the US, e.g. National Security Strategy, National Defense Strategy, Indo-Pacific Strategy and the Elements of the China Challenge report), an aggregated data analysis (data aggregated for the creation of Composite Index of Aggregate Power, data from international institutions, data from the State of Southeast Asia Survey Report), a case study of Southeast Asia and a historical analysis of Sino-US relations.

\footnotetext{
${ }^{6} \mathrm{An}$ analysis of the impact of centralisation in the system on protracted effects of the crisis in reference to Asian economic crises: Marcin Grabowski and Sławomir Wyciślak, 'Contagion and self-learning in Asian economic crises 1997-1998 and 2008-2010. Case study of Malaysia', Research Papers of the Wroclaw University of Economics 413 (2015), 220-32.
} 


\section{POWER TRANSITION THEORY AND CHINA-US RELATIONS: OPPORTUNITY AND WILLINGNESS}

Much of the literature that applies power transition theory to China-US relations focuses on the rapid dynamic economic growth of China, the growing importance of China to international supply chains and the growing strategic importance of China's rare earth elements. ${ }^{7}$ However, much of this literature argues that China does not have the capacity to challenge the US's position as a dominant nation. ${ }^{8}$ Other scholars highlight that a power may be satisfied in a system although it may not be the dominant nation in that system. ${ }^{9}$ This means that it is not capacity alone that drives a state to push for reform, but rather the inability of a system to meet a state's needs. For these scholars, China has benefited from the existing international system. It has pushed for limited reforms within the system to allow it to remain satisfied. ${ }^{10}$

Examples of China's attempts to reform the structure include amending the IMF's and World Bank's voting rights and creating the G20, ${ }^{11}$ as well as creating new international financial institutions such as the Asian Infrastructure Investment Bank, which increased Chinese normative power in international financial governance. ${ }^{12}$ However, Chinese attempts to reform the system are limited by the US, which, as the dominant nation within the hierarchy of nations, ${ }^{13}$ can implement policies to maintain its position at the top of the hierarchy ${ }^{14}$ despite the position of China as a satisfied power. ${ }^{15}$ Some scholars argue that, unable to reform the system, China is moving through different stages of power, from the potential power stage to the transitional stage and finally onto the mature power stage. Theoretically,

\footnotetext{
${ }^{7}$ Woosang Kim and Scott Gates, 'Power transition theory and the Rise of China', International Area Studies Review 18 (3) (2015), 219-26; Zhiqun Zhu, 'Power transition and US-China relations: is war inevitable?', Journal of International and Area Studies 12 (1) (2005), 1-24; Rosemary Foot, 'Power transitions and great power management: three decades of China-Japan-US Relations', Pacific Review 30 (6) (2017), 829-42. Graham Allison, Destined for war: can America and China escape Thucydides's trap? (Boston, 2017).

${ }^{8}$ Henry Kissinger, 'The future of US-Chinese relations: conflict is a choice, not a necessity', Foreign Affairs, 91 (2) (2012), 44-55; Odd Arne Westad, 'The sources of Chinese conduct: are Washington and Beijing fighting a new Cold War?', Foreign Affairs 98 (5) (2019), 86-95.

${ }^{9}$ Abramo Fimo Kenneth Organski, World politics (New York, 1968), 338-76.

${ }^{10}$ Kurt M. Campbell and Jake Sullivan, 'Competition without catastrophe: how America can both challenge and coexist with China', Foreign Affairs 98 (5) (2019), 96-110; Fareed Zakaria, 'The new China scare: why America shouldn't panic about its latest challenger', Foreign Affairs 99 (1) (2020), 52-69; Elbridge A. Colby and Wess Michell, 'The age of great power competition: how the Trump administration refashioned American strategy', Foreign Affairs 99 (1) (2020), 118-30.

${ }^{11}$ Niall Duggan, Wei Shen and Jörn-Carsten Gottwald, 'Global governance with Chinese characteristics?', in Anna Triandafyllidou (ed.), Global governance from regional perspectives: a critical view (Oxford, 2017), $161-80$.

${ }^{12}$ Zhongzhou Peng and Sow Keat To, 'The AIIB and China's normative power in international financial governance structure', Chinese Political Science Review 1 (4) (2016), 736-53.

${ }^{13}$ Roland L. Tammen, Jacek Kugler and Siddharth Swaminathan, 'Power transitions and alliances in the twenty-first century', Asian Perspectives 25 (3) (2001), 5-29.

${ }^{14}$ Douglas Lemke and Jacek Kugler, 'The evolution of the power transition perspective', in Jacek Kugler and Douglas Lemke (eds), Parity and war: evaluations and extensions of the war ledger (Ann Arbor, 1996), 3-34.

${ }^{15} \mathrm{Kim}$ and Gates, 'Power transition theory and the rise of China'; Zhu, 'Power transition and US-China relations'; Foot, 'Power transitions and great power management'.
} 
this final stage will lead to conflict or a hegemonic war between China and the US, resulting in the creation of either a new hegemon or a new multipolar system. ${ }^{16}$

The existing literature that applies power transition theory to China-US relations fails to take into consideration the effect of external shocks in cases where the dominant power, the US, is unwilling or unable to lead a response to an issue that is causing structural change, be it long-term or short-term change. Focusing on how an external shock affects the relationship between a dominant power such as the US and a state such as China, which has the potential to challenge US dominance within the hierarchy of nations, may provide a greater understanding of the power transition process.

\section{FROM RIVAL TO STRATEGIC COMPETITOR}

The end of the Korean War marked the beginning of the early period of USChina relations (1950-1972), which Nansheng Yuan classifies as the period when the US and China moved from the roles of outright enemies to adversaries. ${ }^{17}$ During the same period, much of the foundations of global and regional governance was created. China was not included in this creation of global and regional governance due to its self-imposed isolation and its exclusion by Western powers. ${ }^{18}$ However, since the Shanghai Communiqué (1972) the US has integrated China into global and regional governance. ${ }^{19}$ Despite the anti-Chinese rhetoric of Bill Clinton's and George W. Bush's US presidential campaigns, relations remained rather cooperative, in both strategic and economic terms. ${ }^{20}$ The US welcomed the rise of a stable, peaceful and prosperous China, leading to constructive relations. This resulted in increased Chinese involvement in global and regional governance organisations, such as the WTO, the IMF and the UN, as well as the creation of new bodies such as the G20, where Western powers encouraged China to play a leading role. ${ }^{21}$

\footnotetext{
${ }^{16}$ This article argues that China is in a transitional stage, with the adaptation of an original understanding of 'transitional stage' from the late 1960s approach to a 2020s approach. Therefore China is acquiring and developing industrial (technological) potential, increasing productivity and standard of living, but at the same time experiences a rise in nationalism, government control and autocratic tendencies, causing fears in the international community: Abramo Fimo Kenneth Organski, The power transition: international politics and foreign affairs (New York, 1968), 341-2. In a simplified version, the road to war is almost natural: Allison, Destined for war.

${ }^{17}$ Yuan, 'Reflections on China-US relations after the Covid-19 pandemic'.

${ }^{18}$ Niall Duggan, 'The rise of China within global governance', in Bart Dessein (ed.), Interpreting China as a regional and global power: nationalism and historical consciousness in world politics (London, 2014), 249-79.

${ }^{19}$ Duggan et al., 'Global governance with Chinese characteristics?'.

${ }^{20}$ Marcin Grabowski, 'Selected problems of the US foreign policy in the Asia-Pacific Region after 1989', in Andrzej Mania, Paweł Laidler and Lukasz Wordliczek (eds), US foreign policy: theory, mechanisms, practice (Krakow, 2007), 276-8.

${ }^{21}$ Evelyn Goh, 'Contesting hegemonic order: China in East Asia', Security Studies 28 (3) (2019), 614 44; Niall Duggan and Yves Tiberghien, 'Existing and emerging powers in the G20: the case of East Asia', Asien 128 (2013), 28-44; Nana de Graaff, Tobias ten Brink and Inderjeet Parmar, 'China's rise in a liberal world order in transition - introduction to the FORUM', Review of International Political Economy 27 (2) (2020), 191-207.
} 
However, competition between the US and China began to grow from 2001 onwards, as China increased its economic and military importance in Asia. ${ }^{22}$ The Obama administration revised the US policy of viewing China as a rival and attempted to contain the rise of China in Asia. In 2011, the Obama administration moved the focus of the US to Asia in what was referred to as 'the US Rebalance to Asia' or 'the Asia Pivot'. The pivot entailed strengthening treaty alliances with Australia, Japan, the Republic of Korea and the Philippines, and enhancing the US's defence posture in the region..$^{23}$ The policy also called for deepening partnerships with Indonesia, Malaysia, Singapore, Vietnam and India. ${ }^{24}$ In terms of regional governance, the policy focused on strengthening the region's institutional architecture to reinforce a rules-based order and promoting stronger trade and investment through the Trans-Pacific Partnership (TPP). ${ }^{25}$ The pivot focused on containing China's expanding presence in Asia from a position of strength, but did not see confrontation as inevitable.

In terms of China, the policy looks towards practical cooperation on global challenges such as climate change, public health, economic growth, denuclearisation of the Korean Peninsula and constructive management of differences, such as human rights, Taiwan, cybersecurity and trade imbalances. ${ }^{26}$ However, as Robert Sutter highlighted, ${ }^{27}$ four major areas of contention between China and the US remained: first, the US's support for Taiwan and Tibet, as well as other disputed territories; second, the perception that the US was attempting to change China's political system; third, opposition to the US playing the dominant role within Asia; and finally, Chinese opposition to many aspects of US leadership in world affairs, including the US-backed security presence in the Asia-Pacific area. These areas of conflict, coupled with the appointment of Xi Jinping as China's president in 2013, led China to adopt a more assertive and confrontational approach to foreign policy. ${ }^{28}$ Nevertheless, during the Obama administration, the $\mathrm{Xi}$ administration attempted, with limited success, to work towards practical cooperation with the US on global challenges. ${ }^{29}$

${ }^{22}$ Evan S. Medeiros, 'The changing fundamentals of US-China relations', Washington Quarterly 42 (3) (2019), 93n119; Aaron L. Friedberg, 'Competing with China', Survival 60 (3) (2018), 7-64.

${ }^{23}$ Niall Duggan and Sebastian Bersick, 'China's strategic development in the Asia-Pacific', in Bo Huldt et al. (eds), Strategic yearbook 2012-2013: the emerging global security environment 2012-2013 (Stockholm, 2013), 71-90.

${ }^{24}$ Duggan and Bersick, 'China's strategic development in the Asia-Pacific'.

${ }^{25}$ The White House, 'Fact sheet: advancing the rebalance to Asia and the Pacific', 2015, available at: https:// obamawhitehouse.archives.gov/the-press-office/2015/11/16/fact-sheet-advancing-rebalance-asia-and-pacific (18 June 2021).

${ }^{26}$ The White House, 'Advancing the rebalance to Asia and the Pacific'.

${ }^{27}$ Robert Sutter, 'Barack Obama, Xi Jinping and Donald Trump-pragmatism fails as US-China differences rise in prominence', American Journal of Chinese Studies 24 (2) (2017), 69-85.

${ }^{28}$ Niall Duggan, 'A new Chinese national identity: the role of nationalism in Chinese foreign policy', in Le Zhouxiang (ed.), Chinese national identity in the age of globalisation (Basingstoke, 2020), 161-82.

${ }^{29}$ The White House, 'Remarks by President Obama and President Xi Jinping in joint press conference', 2014, available at: https://obamawhitehouse.archives.gov/the-press-office/2014/11/12/remarks-president-obama-andpresident-xi-jinping-joint-press-conference (18 June 2021). 
The Asia Pivot was a key part of the Obama administration's foreign policy. It can be understood in three dimensions: multilateral diplomacy, military capacity-building and the creation of a new institutional architecture in Asia. ${ }^{30}$ Much of the early scholarship focused on the military dimension of the pivot, including military cooperation in Australia, Singapore and the Philippines. The diplomacy and institutional dimensions received less attention. These dimensions were central to the Obama administration's approach to the region. In terms of the multilateral cooperation dimension, the US's joining the East Asia Summit in November 2011 was a symbolic change in US foreign policy in Asia. In terms of the new economic architecture dimension, the negotiations on the $\mathrm{TPP}^{31}$ were a crucial element of the Asia Pivot. ${ }^{32}$

The Asia Pivot was well received in India, Japan, the Republic of Korea and Taiwan, and even among the US's traditional Australasia allies, which have become increasingly economically interdependent with China. ${ }^{33}$ Several Southeast Asian nations - including the Philippines, Singapore and Vietnam, as well as states such as Thailand, Indonesia and Myanmar, which have become closer to China due to domestic changes - embraced the pivot.

The TPP was the principal aspect of the Obama administration's Asia policy. ${ }^{34}$ The TPP would allow the US to maintain its position as a norm-setter/rule-maker, which it enjoyed in Asia during the 1992-2012 period and which allayed its decreasing relative position in the power distribution in the Asia-Pacific region. The Obama administration approved the final text of the TPP in October 2015 and signed in February 2016. However, the US never ratified the deal, as Donald Trump withdrew the US from the TPP in January 2017.

To fill the void, Japan undertook the position of leadership in the region in terms of creating a new institutional architecture for Asia. Japan led negotiations that resulted in a new agreement between eleven nations, known as the Comprehensive Progressive Trans-Pacific Partnership, signed in March $2018 .{ }^{35}$ Donald Trump's election to the US presidency in 2016 had seen the US adopt a more assertive approach, and it became more confrontational

\footnotetext{
${ }^{30}$ Kurt Campbell, The pivot: the future of American statecraft in Asia (New York, 2016).

${ }^{31}$ Marcin Grabowski, 'Will Trans-Pacific Strategic Partnership Agreement increase the competitiveness of the Asia-Pacific Region?', in Bogusława Skulska and Anna H. Jankowiak (eds), Faces of competitiveness in Asia Pacific (Wroclaw, 2011), 61-73.

${ }^{32}$ Mark E. Manyin, Stephen Daggett, Ben Dolven, Susan V. Lawrence, Michael F. Martin, Ronald O'Rourke and Bruce Vaughn, Pivot to the Pacific? The Obama administration's 'rebalancing' toward Asia (Washington, DC, 2012).

${ }^{33}$ Robert G. Sutter, The United States and Asia: regional dynamics and twenty-first-century relations (Lanham, 2020).

${ }^{34}$ Michael Yahuda, The international politics of the Asia-Pacific (London, 2019), 131-2; Bates Gill, 'The United States and Asia in 2015: across the region, US-China competition intensifies', Asian Survey 56 (1) (2016), 8-18; Bates Gill, 'The United States and Asia in 2016: challenges in the region and on the home front', Asian Survey 5 (1) (2017), 10-20.

${ }^{35}$ Deborah Elms, The comprehensive and progressive Trans-Pacific Partnership: policy innovations and impacts (Geneva, 2018), 1-22.
} 
with China. As Nansheng Yuan highlighted ${ }^{36}$ the Trump administration regarded China as 'a revisionist state, implying that China is dissatisfied with the US-led international order and, thus, hopes to revise the status quo'. This shift towards China as a strategic competitor resulted in China's failing to increase its power in bodies such as the World Bank and the IMF. ${ }^{37}$ China then began creating its own global and regional institutions, such as the Asian Infrastructure Investment Bank and the Belt and Road Initiative.

\section{DIMENSIONS OF AMERICAN AND CHINESE POWER}

Assessing relative distribution of power in the international system is difficult. Scholars such as Edward Carr, Nicholas Spykman, Hans Morgenthau, Kenneth Waltz, Robert Gilpin and Ray Cline have all attempted to create power-measuring formulas, with varying levels of success. These works have received criticism due to their oversimplified approaches to power measurement, focusing on gross indicators and hence not considering the costs related to maintenance of large population or military. Therefore, Michael Beckley recommends a net measurement of power, which in the case of the US proves much higher prevalence over China. ${ }^{38}$

The Cline formula remains popular due to its relative simplicity. It focuses on critical mass - that is, territory and population, economic capability, military capability and multipliers, such as strategic purpose, including the will to pursue strategy. However, the Cline formula does not fully develop the strategic purpose criteria. Enrico Fels attempted to solve this problem by removing discretionary criteria and created the so-called Composite Index on Aggregate Power (CIAP). CIAP is based on 55 quantitative variables reflecting three broad categories: critical mass (size of territory and size of population), economic capability (including size of domestic economy, energy supply and dependence, critical non-fuel minerals, industrial output, food production and dependency, trade and finance) and military capability (including conventional weaponry, total defence spending, defence spending as share of GDP, overall manpower, troops stationed abroad, and nuclear armament). ${ }^{39}$ Fels applied the CIAP to the aggregated power of 44 AsiaPacific countries from 1992 to $2012^{40}$ and found that the US had been the dominant power in the Asia-Pacific region during that time, but its power has decreased relative to other regional actors, with the exception of Japan.

\footnotetext{
${ }^{36}$ Yuan, 'Reflections on China-US relations after the CovID-19 pandemic', 14.

${ }^{37}$ Nana de Graaff, Tobias ten Brink and Inderjeet Parmar, 'China's rise in a liberal world order in transition - introduction to the FORUM', Review of International Political Economy 27 (2) (2020), 191-207.

${ }^{38}$ Michael Beckley, 'China's century? Why America's edge will endure', International Security 36 (3) (2012), 41-78; Michael Beckley, 'The power of nations: measuring what matters', International Security 43 (2) (2018), 7-44.

${ }^{39}$ The analysis of Cline's formula and methodology of CIAP (including all the metrics for each of 55 variables). E. Fels, Shifting power in Asia-Pacific? The rise of China, Sino-US competition and regional middle power allegiance (London, 2017), 227-51.

${ }^{40} \mathrm{CIAP}$ I, with weight 1 for critical mass, 2 for economic power and 2 for military power. This version of CIAP is more favourable for the US.
} 
Fels found that China's power amounted to only $34.7 \%$ of the US's power in 1992 but had risen to $89.4 \%$ by $2012 .{ }^{41}$

The relative distribution of power has also been unfavourable for the US in the Asia-Pacific region. However, a key element of Fels's approach is middle power allegiance, which, in the case of the US, includes Australia, Pakistan, Japan, the Republic of Korea, Thailand and Indonesia. Fels highlights that only Pakistan moved towards closer allegiance with China between 1992 and 2012. The remaining middle powers in the region moved towards closer collaboration with the US. ${ }^{42}$ Beyond these middle powers, the US has developed further links in the region by creating the concept of quadrilateral security dialogue between the US, Australia, Japan and India. This concept is linked to the wider IndoPacific strategy, as well as with other regional bilateral alliances.

The US's dominant position in international organisations allows it to maintain its strategic advantage, despite declining relative power, as reflected in CIAP. The US, with its $16.51 \%$ vote in the $\mathrm{IMF}^{43}$ has a de facto veto in the most important issues the IMF faces. The US enjoys a similar position in the World Bank with a $15.44 \%{ }^{44}$ vote. It boasts a $20.98 \%$ vote in the International Financial Corporation, ${ }^{45}$ a $10.06 \%$ vote in the International Development Association ${ }^{46}$ and a $15.01 \%$ vote in the Multilateral Investment Guarantee Agency. ${ }^{47}$ In Asia, the US holds a $15.6 \%$ share of the Asian Development Bank, ${ }^{48}$ matched only by its close ally, Japan. This has allowed the US to maintain economic influence in Asia. The US also uses its membership of the Asia-Pacific Economic Cooperation (APEC) to reinforce its position in Asia. The TPP was engineered to allow the US to maintain its dominant position in Asia. However, the withdrawal of the US from the TPP has limited its strategic advantage. ${ }^{49}$

The US is also facing a decline in terms of soft power. This is due to its military superpower status, the rise of anti-globalisation sentiments worldwide, US isolation from agreements and institutions strongly supported by the

${ }^{41}$ Fels, Shifting power in Asia-Pacific?, 322.

${ }^{42}$ Fels, Shifting power in Asia-Pacific?, 365-74.

${ }^{43}$ International Monetary Fund, 'IMF members' quotas and voting power, and IMF Board of Governors', 2020, available at: https://www.imf.org/external/np/sec/memdir/members.aspx (18 June 2021).

${ }^{446}$ International Bank for Reconstruction and Development subscriptions and voting power of member countries', 2021, available at: http://pubdocs.worldbank.org/en/795101541106471736/IBRDCountryVotingTable.pdf (18 June 2021).

${ }^{45}$ 'International Finance Corporation subscriptions and voting power of member countries', 2021, available at: http://pubdocs.worldbank.org/en/280961541106482420/IFCCountryVotingTable.pdf (18 June 2021).

${ }^{46}$ International Development Association voting power of member countries', 2021, available at: http:// pubdocs.worldbank.org/en/845861541106477171/IDACountryVotingTable.pdf (18 June 2021).

${ }^{47}$ 'Multilateral Investment Guarantee Agency subscriptions and voting power of member countries', 2021, available at: http://pubdocs.worldbank.org/en/324001541106504233/MIGACountryVotingTable.pdf (18 June 2021).

${ }^{48}$ Asian Development Bank, 'Shareholders', 2021, available at: https://www.adb.org/site/investors/credit-fundamentals/shareholders (18 June 2021).

${ }^{49}$ Marcin Grabowski and Tomasz Pugacewicz, 'Is Trans-Pacific Partnership a challenge for transatlantic relations? A comparative analysis of TPP and TTIP in the context of the US global role', in Małgorzta Zachara (ed.), Poland in transatlantic relations after 1989: miracle fair (Newcastle upon Tyne, 2017), 86-124. 
international community, the response of the US after $9 / 11$ and the perception of US government incompetence..$^{50}$ The role of the US in the 2008 global financial crisis and its effect on the global economy has also been a factor in the decline of US soft power. The crisis weakened US soft power in Asia, as it allowed a concomitant increase in China's role in the international system when responding to the crisis. ${ }^{51}$ In response to this decline, the US moved towards a smart power strategy - that is, containing elements of hard and soft power and focusing on support for global development, public diplomacy, economic integration, and technological development through alliances, partnerships and institutions. $^{52}$

Moreover, the power of the US is in relative decline in terms of the comparative advantage in the system. The US has compensated for this decline by cooperating with allies and leveraging its position in international organisations and agreements, an approach that has differed under each US administration. A lack of proper use of components of American power (leadership in international institutions, the creation of norms and rules, and cooperation with allies) may have been visible especially during the Trump administration. However, in terms of power, a transition between the US and China in line with the theory outlined by Abramo Fimo, Kenneth Organski and Jacek Kugler remains debatable.

\section{THE TRUMP ADMINISTRATION AND THE SINO-AMERICAN TRADE WAR}

The US's trade deficit with China stood at USD378 billion in 2018, up from USD103.1 billion in 2002. ${ }^{53}$ In 2018, the trade deficit with China accounted for almost half of America's trade deficit with the entire world. ${ }^{54}$ The deficit was a major focus of the US presidential campaign in 2016. On his campaign trail, candidate Donald Trump promised to reduce the large trade deficit with China, which he claimed was based on unfair trading practices such as Chinese subsidies of Chinese companies, intellectual property theft, currency manipulation and lack of access to the Chinese market for American companies. ${ }^{55}$ In China,

${ }^{50}$ Joseph S. Nye and Richard S. Armitage, A smarter, more secure America: report of the Center for Strategic and International Studies (Washington, 2007). Regional relations of the United States, including those with Southeast Asia, Northeast Asia and South Asia were also analysed in the document, pp. 21-25.

${ }^{51}$ More on those crises: Marcin Grabowski and Sławomir Wyciślak, 'The impact of the Asian economic crises 1997-1998 and 2008-2009 on regional security and development', in Marcin Grabowski and Pawel Laidler (eds), Global development policy in the 21st century: new challenges (Berlin, 2018), 37-61.

${ }^{52}$ Nye and Armitage, A smarter, more secure America.

${ }^{53}$ United States Census Bureau, Trade in goods with China', 2021, available at: https://www.census.gov/foreign-trade/balance/c5700.html (18 June 2021).

${ }^{54}$ In 2016 the US trade in goods deficit with the world (seasonally adjusted) amounted to $\$ 735$ billion, followed by $\$ 793$ billion in 2017 and $\$ 875$ billion in 2018. United States Census Bureau, Trade in goods with world, seasonally adjusted, 2020, available at: https://www.census.gov/foreign-trade/balance/c5700.html (18 June 2021).

${ }^{55}$ Michael Beckley, 'The end of the affair: US-China relations under Trump', in Stanley A. Renshon and Peter Suedfeld (eds), The Trump doctrine and the emerging international system: the evolving American presidency (Cham, 2021), 227-45. 
this move was framed as part of a wider US policy of restricting China's rise as a regional and global power.

In terms of the trade surplus with China, the Trump administration applied a number of tariffs based on old Cold War legislation, including section 201 of the 1974 Trade Act used to impose tariffs on washing machines and solar panel imports in March 2018, section 232 of the 1962 Trade Expansion Act used to impose tariffs on steel and aluminium imports in April 2018, and section 301 of the 1974 Trade Act becoming the basis for further tariffs covering virtually all imports from China. China retaliated to the imposition of tariffs during the Trump administration trade war, which had limited success due to the negative effect on investment, sovereign bonds holdings, etc., between China and the US. The trade war led to economic losses on both sides. ${ }^{56}$ The simulation made on the SMART model indicated a US import reduction from China of $c$.USD91.4 billon and a Chinese import reduction from the US of c.USD36.7 billion. This caused a trade diversion effect (in the case of US imports, Mexico, Japan and Germany, and similarly China's imports-Brazil, Germany, Japan, Argentina, UK, Canada), resulting in limited utility, with welfare losses on both sides. ${ }^{57}$ On the other hand, the trade war may be perceived as another coercive diplomacy tool, limiting the Chinese position in the global system and thus hampering a power transition. ${ }^{58}$

To confront the rise of China as a strategic competitor, the Trump administration attempted to introduce a new pivot to Asia policy: the Free and Open Indo-Pacific. This policy highlighted the challenges to cooperation with China, which was limited by a series of economic and military threats presented by China. The Free and Open Indo-Pacific policy also focused on North Korea in the context of cybersecurity and missile and nuclear programmes. Furthermore, the US policy reaffirmed alliance commitments to Japan, the Republic of Korea, Australia and New Zealand, with a focus on the new strategic-military component of the Indo-Pacific concept, the Quadrilateral Security Dialogue (Quad). In Southeast Asia, traditional allies Thailand and the Philippines were brought to the fore, as were Vietnam, Indonesia, Malaysia and Singapore. Regional

\footnotetext{
${ }^{56}$ For further details of Sino-American economic relations and the trade war, see Congressional Research Service, 'US-China tariff actions by the numbers' (2019), available at: https://fas.org/sgp/crs/row/R45949.pdf (10 October 2019); Congressional Research Service, 'US-China trade and economic relations: overview', 2019, available at: https://fas.org/sgp/crs/row/IF11284.pdf (10 October 2019); Susan Lawrence, Caitlin Campbell, Rachel Fefer, Jane Leggett, Thomas Lum, Michael Martin and Thomas Schwarzenberg, 'US-China relations', 2019, available at: https://fas.org/sgp/crs/row/R45898.pdf (10 October 2019). For doubts on actual effects of the trade war, see Miaojie Yu and Rui Zhang, 'Understanding the recent Sino-US trade conflict', China Economic Journal 12 (2) (2019), 160-74; Liugang Sheng, Hongyan Zhao and Jing Zhao, 'Why will Trump lose the trade war?', China Economic Journal 12 (2) (2019), 137-59; Jeffrey Sachs, 'Will America create a cold war with China?', China Economic Journal 12 (2) (2019), 100-8.

${ }^{57}$ Xinquan Tu, Yingxin Du, Yue Lu and Chengrong Lou, 'US-China trade war: is winter coming for global trade?', Journal of Chinese Political Science 25 (2000), 199-240.

${ }^{58} \mathrm{Min}$ Ye, 'The Covid-19 effect: US-China narratives and realities', Washington Quarterly 44 (1) (2021), 89-105; Zuo Xiying, 'The Trump effect: China's new thoughts on the United States', Washington Quarterly 44 (1), 107-27.
} 
bodies such as the Association of Southeast Asian Nations (ASEAN) and APEC were highlighted as institutions that the US would support in promoting freedom-based regional order. Commitments to Taiwan and support for strong partnership with India were also key aspects of the Free and Open Indo-Pacific policy. ${ }^{59}$ The policy goals generally resembled those of Obama's Asia Pivot.

Trump's Free and Open Indo-Pacific policy was integrated into the 2018 National Defense Strategy, which predominantly addressed China. The document portrayed China as attempting to remodel the Indo-Pacific order. It explicitly indicated that the rise of the Chinese economic and military position would be followed by a regional struggle for hegemony and the removal of the US from this position. ${ }^{60}$

At the 2017 APEC summit in Vietnam, Donald Trump outlined his vision for the region:

- respect for sovereignty and independence

- peaceful conflict resolution

- free, fair and reciprocal trade that should be based on open investment as well as transparent agreements and links

- adjustment to international norms and rules, including freedom of navigation and flights. ${ }^{61}$

Following this declaration, the Trump administration issued a strategic document defining US strategy in the Indo-Pacific region during 2019. The IndoPacific Strategy Report: Preparedness, Partnerships, and Promoting a Networked Region was published by the Department of Defense ${ }^{62}$ in June 2019. It defined the US as a Pacific nation and focused on the Indo-Pacific region as a key operational platform for the US. The report clearly outlines that the US's vision for a free and open Indo-Pacific clashes with Chinese aspirations in the region-that is, to undermine the regional governance structure, which is based on Western norms and values. Therefore, the report stressed a need for the US to take action to protect regional order. Such action would include military operations, containment of possible conflicts, partnerships to strengthen existing alliances, new agreements and the promotion of regional networks. ${ }^{63}$

\footnotetext{
${ }^{59}$ White House, 'National Security Strategy of the United States of America', 2017, available at: https:// www.whitehouse.gov/wp-content/uploads/2017/12/NSS-Final-12-18-2017-0905.pdf (15 April 2020).

${ }^{60}$ Department of Defense, 'Summary of the National Defense Strategy: sharpening the American military's competitive edge', 2018, available at: https://dod.defense.gov/Portals/1/Documents/pubs/2018-National-Defense-Strategy-Summary.pdf (15 April 2020).

${ }^{61}$ Department of Defense, 'Summary of the National Defense Strategy'.

${ }^{62}$ Department of Defense, 'Indo-Pacific strategy report: preparedness, partnerships, and promoting a networked region', 2019, available at: https://media.defense.gov/2019/jul/01/2002152311/-1/-1/1/department-of-defense-indo-pacific-strategy-report-2019.pdf (18 June 2021).

${ }^{63}$ Department of Defense, 'Indo-Pacific strategy report'.
} 
The strategic goals of the policy were defined in reference to key challenges, such as Russia and North Korea, followed by specific actions, such as development of strategic infrastructure (Joint Pacific Alaska Range Complex) and improvement of combat readiness of the US Air Force. ${ }^{64}$ The policy also focused on regional alliances and partnerships, specifically the need for sharing the security burden. Transitional allied nations including Japan, the Republic of Korea, Australia, the Philippines and Thailand were highlighted, but the document also stressed deepening partnerships with Singapore, Taiwan, New Zealand, Mongolia, India, Sri Lanka, the Maldives, Bangladesh, Vietnam, Indonesia and Malaysia. Countries that have been perceived as falling under the Chinese sphere of influence, such as Brunei, Laos and Cambodia, were highlighted as targets for new military cooperation. Finally, the document focused on trilateral and multilateral cooperation, especially within the ASEAN Regional Forum and the East Asia Summit. ${ }^{65}$

Following the Indo-Pacific Strategy Report, the Trump administration launched a policy that targeted the challenges that the US faces due to the Chinese rise to power. This policy, entitled 'The Elements of the China Challenge', was published in November 2020 by the Office of the Secretary of State. ${ }^{66}$ It was set to be the foundation of US China strategy for Trump's second term. The document planned to move US policy towards a new era of great power competition. The main area of conflict would occur if China refused to work within the current system of global governance and, instead, attempted to create a China-centric international system. ${ }^{67}$ This would require China to develop military and economic capacity in the IndoPacific, but also to increase its influence in Russia, Europe, the Middle East and Africa. The document also highlighted to the US the challenge of China transforming international organisations from within those organisations. ${ }^{68}$

Both the Indo-Pacific Strategy Report and 'The Elements of the China Challenge', as well as the Sino-American trade war launched by Trump's administration, were clear attempts to maintain the US's position as a dominant nation in the international system. The policy was a continuation of Obama's strategy that aimed at limiting Chinese influence in the region, but Trump's policy took a more confrontational approach. The CovID-19 pandemic was the first major event to affect the relative distribution of power in the global system,

\footnotetext{
${ }^{64}$ From this report, in the region within the scope of the Indo-Pacific Command the US has 2,000 planes, 200 naval vessels and 370,000 personnel deployed. Most of them are in Japan and South Korea and at Guam. Additional personnel are deployed permanently or rotationally in the Philippines, Australia, Singapore and (British) Diego Garcia island. Department of Defense, 'Indo-Pacific strategy report', 19.

${ }^{65}$ Department of Defense, 'Indo-Pacific strategy report', 21-49.

${ }^{66}$ US Department of State, 'The elements of the China challenge', available at: https://www.state.gov/ wp-content/uploads/2020/11/20-02832-Elements-of-China-Challenge-508.pdf (18 June 2021).

${ }^{67}$ US Department of State, 'Elements of China challenge'.

${ }^{68}$ US Department of State, 'Elements of China challenge', 8-26.
} 
particularly in Asia, since the launch of these strategy reports by the Trump administration.

\section{COVID-19 AND US-CHINA RELATIONS}

The Covid-19 pandemic was first identified in December 2019 in Wuhan, China. The WHO declared Covid-19 a global pandemic on 11 March 2020. The global economic impact of Covid-19 has created one of largest slowdowns in production since the Second World War. ${ }^{69}$ In April 2020, Henry Kissinger forecast that the CovID-19 pandemic would forever alter the world order. ${ }^{70}$

In terms of power transition, the CovID-19 pandemic has had three major effects on Sino-American relations. First, the pandemic has, at least in the short term, affected the economic performance of both China and the US. However, the US has been more vulnerable to the negative economic effects of the pandemic in terms of international trade. ${ }^{71}$ GDP growth in the US fell from $2.2 \%$ in 2019 to $-3.5 \%$ in 2020, and GDP in China grew 2.3\% in 2020, down from 5.9\% in $2019 .{ }^{72}$ The US has felt the impact of the pandemic more severely, with exports dropping from USD1,643 billion in 2019 to USD1,432 billion in 2020, a reduction of $13.5 \%$. China's exports increased by 3.5\%, from USD2,499 billion in 2019 to USD2,590 billion in 2020 . $^{73}$

The second major impact of the pandemic has been to compound the US's disengagement from international organisations under the Trump administration. The fallout from Trump's actions accelerated during the Covid-19 pandemic and catalysed a trend of slowing globalisation and increasing regionalisation, visible in production value-added chains and trade patterns. ${ }^{74}$ Under Trump, the US withdrew from and defunded a number of important international treaties and organisations, such as the Joint Comprehensive Plan of Action with the P5+1 and Iran; the UN Human Rights Council (UNHRC); the Global Compact for Safe, Orderly and Regular Migration; the Global Compact on Refugees; the UN Relief and Works Agency (UNRWA); the Paris

\footnotetext{
${ }^{69}$ Jasper Verschuur, Elco E. Koks and Jim W. Hall, 'Global economic impacts of Covid-19 lockdown measures stand out in high-frequency shipping data', PLoS ONE 16 (4) (2021), e0248818.

${ }^{70}$ Henry Kissinger, 'The coronavirus pandemic will forever alter the world order', Wall Street Journal, 3 April 2020.

${ }^{71}$ Wei Tian, 'How China managed the Covid-19 pandemic', Asian Economic Papers 20 (1) (2021), 75-101; Xiaolan Fu, Jing Zhang and Liming Wang, 'Introduction to the special section: the impact of Covid-19 and post-pandemic recovery: China and the world economy', Journal of Chinese Economic and Business Studies 18 (4) (2020), 311-19.

${ }^{72}$ World Bank, World Development Indicators, available at: https://databank.worldbank.org/indicator/ NY.GDP.MKTP.KD.ZG/1ff4a498/Popular-Indicators (15 October 2021).

${ }^{73}$ World Trade Organization, 'WTO stats', available at: https://timeseries.wto.org/?idSavedQuery=fd0b75cc-3db8-4f9c-aab9-7c5609885534 (15 October 2021).

${ }^{74}$ Wang and Sun, 'From globalization to regionalization'. For changing trends in regionalisation v. globalisation, Marcin Grabowski, 'Regionalism: cooperation and conflict', in Andrzej Mania, Marcin Grabowski and Tomasz Pugacewicz (eds), Global politics in the 21st century: between regional cooperation and conflict (Berlin, 2019), 15-24.
} 
Agreement; and the WHO Constitution. On 6 July 2020, the US ${ }^{75}$ indicated its formal intent to withdraw, effective 6 July 2021, from the UNESCO Constitution, the Intermediate-Range Nuclear Forces Treaty, the Treaty on Open Skies, the Optional Protocol to the Vienna Convention on Diplomatic Relations: Vienna Convention on the Law of Treaties (VCLT) and the Treaty of Amity, Economic Relations and Consular Rights with Iran.

The withdrawal of the US from these organisations and treaties shortly before the pandemic opened a power vacuum within various aspects of global governance. In particular, the de facto withdrawal of the US from the WHO under the Trump administration prevents the US from undertaking global leadership in response to the pandemic. President Trump directly blamed the WHO for the failure to respond quickly to the pandemic, claiming it was too 'China-centric' and that 'The WHO really blew it. ${ }^{76}$ In turn, the WHO moved towards closer cooperation with China in order to respond to the pandemic. ${ }^{77}$ The US - by withdrawing funding from the WHO — has increased China's relative power within an international organisation that is taking a leading role in response to the pandemic not only in Asia but also within the Global South. ${ }^{78}$

The third major impact of Covid-19 on US-China relations in terms of the transition of power has been the lack of US leadership in the global response to the worldwide shortage of personal protective equipment (PPE $)^{79}$ and other medical equipment needed to deal with the pandemic. While the US under Trump followed its 'America First' policy, even preventing 200,000 US-made masks from being shipped to Germany, ${ }^{80}$ China engaged in mask diplomacy: in an attempt to bolster its image as a responsible global power, the Chinese state sent planeloads of masks and medical equipment to the countries hardest hit by the pandemic. ${ }^{81}$ China has also engaged in direct military-to-military cooperation with developing countries in Asia, the Middle East and Africa, and assisted militaries in Eastern Europe and Latin America to train armies to deal with the pandemic. ${ }^{82}$

Some scholars have claimed that Chinese mask diplomacy led to China's taking a leading role in the response to CoviD-19, resulting in the developing world and several of the US's traditional allies turning to China for help during

\footnotetext{
${ }^{75}$ Katie Rogers and Apoorva Mandavilli, 'Donald Trump administration signals formal withdrawal from WHO', New York Times, 7 July 2020.

${ }^{766}$ Coronavirus: Trump attacks "China-centric" WHO over global pandemic', BBC News, 8 April 2020.

${ }^{77}$ CCoronavirus: Trump attacks "China-centric" WHO over global pandemic'.

${ }^{78}$ Suisheng Zhao, 'Rhetoric and reality of China's global leadership in the context of CoviD-19: implications for the US-led world order and liberal globalization', Journal of Contemporary China 30 (128) (2021), 233-48.

${ }^{79}$ Bates Gill, 'China's global influence: post-Covid prospects for soft power', Washington Quarterly 43 (2) (2020), 97-115.

${ }^{80}$ CCoronavirus: US accused of "piracy" over mask "confiscation"”, BBC News, 4 April 2020.

${ }^{81}$ Bartosz Kowalski, 'China's mask diplomacy in Europe: seeking foreign gratitude and domestic stability', Journal of Current Chinese Affairs (2021), https://doi.org/10.1177/18681026211007147; Raj Verma, 'China's "mask diplomacy" to change the CovID-19 narrative in Europe', Asia Europe Journal 18 (2) (2020), 205-9.

${ }^{82}$ Helena Legarda, 'The PLA's mask diplomacy', 2020, available at: https://merics.org/en/tracker/ plas-mask-diplomacy (18 June 2021).
} 
the early stages of the pandemic. ${ }^{83}$ Others have suggested that Chinese vaccine diplomacy has followed a similar pattern to its mask diplomacy, albeit less effectively, and has increased Chinese soft power in the Global South. ${ }^{84}$ However, the success of China's mask and vaccine diplomacy in increasing China's soft power has been questioned by the China Power Project at the Center for Strategic and International Studies (CSIS). The CSIS noted that $96 \%$ of Chinese-produced vaccines exported were purchased rather than donated, and only $2 \%$, or five million doses, ended up going to low-income countries. ${ }^{85}$ In terms of PPE, more than $99 \%$ was purchased, with the US, Germany, Japan and the United Kingdom purchasing more than $50 \%$ of Chinese PPE exports in $2020{ }^{86}$ This suggests that China's actions were commercially motivated and were not targeted at the Global South. The CSIS highlights that China's medical diplomacy did not increase China's influence beyond the countries with which it had a substantial or strong relationship prior to the pandemic. ${ }^{87}$ The CSIS study suggests that any increased influence was short-lived as questions arose regarding the quality of Chinese PPE and the effectiveness of the Chinese vaccine, which dented China's positive image ${ }^{88}$. The election of President Joe Biden and his return to a policy of multilateral cooperation, as well as the central role of US pharmaceutical companies, may also have influenced the effectiveness of Chinese vaccine diplomacy, which the CSIS claims was less successful than China's mask diplomacy among traditional US allies. ${ }^{89}$

The three major impacts of the CovID-19 pandemic on Sino-US relations in terms of power dynamics suggest that the pandemic has accelerated China's rise in power, causing a lowering of the US's relative position. This is a consequence of the US's decision to reduce its dominant global position under the Trump administration. If this is indeed the case, it should be evident in Southeast Asia - a region where the two actors compete for influence and where power

\footnotetext{
${ }^{83}$ Verma, 'China's "mask diplomacy" to change the Covid-19 narrative in Europe'; Diego Telias and Francisco Urdinez, 'Mask diplomacy in Latin America and the Caribbean (MDLAC) Dataset v. 1.0', Pontifical Catholic University of Chile UC Center for Asian Studies, available at: https://www.estudiosasiaticos.uc.cl/ humanidades-digitales/maskdiplomacy-v-1-0 (8 November 2021); Istvan Engelberth and Jadit Sagi, 'Mask diplomacy: China-Africa relations in the light of Coronavirus pandemic', Contemporary Chinese Political Economy and Strategic Relations 7 (1) (2021), 3-44; Yanqiu Rachel Zhou, 'Vaccine nationalism: contested relationships between COVID-19 and globalization', Globalizations (2021), doi: 10.1080/14747731.2021.1963202.

${ }^{84}$ S. T. Lee, 'Vaccine diplomacy: nation branding and China's Covid-19 soft power play', Place Branding and Public Diplomacy (2021), doi: 10.1057/s41254-021-00224-4; A. Kobierecka and M.M. Kobierecki, 'Coronavirus diplomacy: Chinese medical assistance and its diplomatic implications', International Politics 58 (2021), 937-54.

${ }^{85}$ ChinaPower, 'Is China's Covid-19 diplomacy succeeding?', available at: https://chinapower.csis.org/china-covid-medical-vaccine-diplomacy/ (9 November 2021).

${ }^{86}$ ChinaPower, 'Is China's Covid-19 diplomacy succeeding?'

${ }^{87}$ ChinaPower, 'Is China's Covid-19 diplomacy succeeding?'

${ }^{88}$ ChinaPower, 'Is China's Covid-19 diplomacy succeeding?'

${ }^{89}$ The Economist, 'Vaccine diplomacy boosts Russia's and China's global standing', 19 April 2021; Michael Leigh, 'Vaccine diplomacy: soft power lessons from China and Russia?', 27 April 2021, available at: https:/ www.bruegel.org/2021/04/vaccine-diplomacy-soft-power-lessons-from-china-and-russia/ (18 June 2021); ChinaPower, 'Is China's Covid-19 diplomacy succeeding?'.
} 
transition is most likely to take place due to its geographical location, as well as its economic and cultural links to China.

\section{CHINA'S RISE IN SOUTHEAST ASIA DURING THE COVID-19 PANDEMIC}

Sino-American strategic rivalry in Southeast Asia has increased since the beginning of the $\mathrm{Xi}$ administration in $2013 .{ }^{90}$ China has increased its influence in the region in terms of its economic engagement but also in terms of security, as it pushes its sovereignty claims in the South China Sea. ${ }^{91}$ The US has also increased its presence by promoting the Free and Open Indo-Pacific strategy, a policy that focuses on challenging China's expanding influence. ${ }^{92}$ Southeast Asia is the most likely case for power transition between China and the US.

Covid-19 has had significant influence on Sino-American strategic rivalry in Southeast Asia. The State of Southeast Asia: 2021 Survey Report published by the ASEAN Studies Centre of the ISEAS Yusof Ishak Institute in Singapore examined the US-China rivalry. The report is based on a survey of opinion leaders within ten ASEAN states. Respondents represent academia, think-tanks and research institutions (45.4\%); business and finance $(9.2 \%)$; civil society, NGOs or media $(9.3 \%)$; government $(30.7 \%)$; and regional or international organisations $(5.3 \%)$. Due to the high-profile nature of the respondents, this survey provides an accurate picture of the state of the region, including crucial challenges to Southeast Asia. The report highlighted that $76 \%$ of respondents stated that the pandemic was their most pressing concern. ${ }^{93}$ Only $9.6 \%$ of respondents saw the US as the main provider of help in the ASEAN region, while 44\% saw China as the key provider of help. China was also deemed the most influential economic power in Southeast Asia (76.3\% of respondents). ${ }^{94}$ This trend has held consistently since 2019 , when $73.3 \%$ of respondents regarded China as the most influential economic power in the region; in 2020 the figure was $79.2 \% .^{95} 7.4 \%$ of respondents in 2021 regarded the US as the most influential economic power in the region, down from $7.9 \%$ in 2020 and $2019 .{ }^{96}$ CovID-19 has played a part in cementing China's position as the most influential economic power in Southeast Asia: ASEAN became one of China's top trading partners in terms of volume

\footnotetext{
${ }^{90}$ Jonathan R. Stromesth, 'Navigating great power competition in Southeast Asia', Rivalry and response: assessing great power dynamics in Southeast Asia (Washington, DC, 2021), 1-31; ChengChwee Kuik, 'The twin chessboards of US-China rivalry: impact on the geostrategic supply and demand in post-pandemic Asia', Asian Perspective 45 (1) (2020), 157-76; David Shambaugh, 'US-China rivalry in Southeast Asia: power shift or competitive coexistence?', International Security 42 (4) (2018), $85-127$.

${ }^{91}$ Duggan and Bersick, 'China's strategic development in the Asia-Pacific'.

${ }^{92}$ Stromesth, 'Navigating great power competition in Southeast Asia'.

${ }^{93}$ Sharon Seah, Hoang Thi Ha, Melinda Martinus, Pham Thi and Phuong Thao, The state of Southeast Asia: 2021 survey report (Singapore, 2021).

${ }^{94}$ Seah et al., State of Southeast Asia, 20.

${ }^{95}$ Seah et al., State of Southeast Asia, 20.

${ }^{9}$ Seah et al., State of Southeast Asia, 20.
} 
of trade, and each partner became a key source of investment in the other's economy. ${ }^{97}$

Beyond China's economic engagement in Southeast Asia, it was seen as the most influential political-strategic power in the region in 2020 and 2021. China was most influential in Laos (65.0\%), Cambodia (61.5\%), Thailand (58.8\%) and Myanmar (51.9\%). The Philippines was the only nation in the region to choose the US over China as the most influential political-strategic power. ${ }^{98}$ China has used its new economic and political-strategic power to create a new institutional architecture for the region-for example, the Regional Comprehensive Economic Partnership (RCEP) agreement signed in November 2020. RCEP is a trade and investment agreement among ASEAN member states, Australia, China, Japan, New Zealand and the Republic of Korea, and is now the world's largest trade bloc. While it is inaccurate to label the RCEP as Chinese, China did play a leading role in its creation..$^{99}$ Overall, $63.2 \%$ of respondents agree that the RCEP will help trade and investment in their country. China's economic and political-strategic power has also led $46.3 \%$ of respondents to view China as a revisionist power that intends to turn the region towards its sphere of influence, while $31.5 \%$ of respondents stated that China is gradually usurping the US in the role of regional leader.

In $2021,72.3 \%$ of respondents to the survey worried about the growing regional economic influence of China, and $88.6 \%$ were anxious about China's growing strategic influence. These anxieties were particularly high among respondents from Vietnam (97.7\%), the Philippines $(95.0 \%)$ and Thailand $(92.2 \%){ }^{100}$ China's involvement in territorial and maritime disputes as well as its economic ambitions are by far the main drivers of this anxiety. ${ }^{101}$ The fear of China's rise in the region has pushed ASEAN member states towards the US. Despite the economic importance of China to ASEAN, $61.5 \%$ of respondents in 2021 would choose the US if forced to choose between China and the US as a strategic partner. Only Myanmar (51.9\%), Brunei $(69.7 \%)$ and Laos $(80.0 \%)$ preferred China. ${ }^{102}$ The election of Joe Biden to the US presidency increases the positive outlook for the US role in the region, with $68.6 \%$ of respondents predicting that US engagement will increase. By contrast, $77 \%$ of respondents expected the US's role to decrease under the Trump administration. ${ }^{103}$ The perception that the US is a reliable strategic partner increased to 55.4\% since Biden's election, from $34.9 \%$ under the Trump administration. ${ }^{104}$

\footnotetext{
${ }^{97}$ ASEAN, ASEAN statistical yearbook 2020 (Jakarta, 2020).

${ }^{98}$ Seah et al., State of Southeast Asia, 22.

${ }^{99}$ Jeffrey D. Wilson, 'Mega-regional trade deals in the Asia-Pacific: choosing between the TPP and RCEP?', Journal of Contemporary Asia 45 (2) (2015), 345-53; Peter Drysdale and Shiro Armstrong, 'RCEP: a strategic opportunity for multilateralism', China Economic Journal 14 (2) (2021), 128-43.

${ }^{100}$ Seah et al., State of Southeast Asia, 22.

${ }^{101}$ Seah et al., State of Southeast Asia, 38.

${ }^{102}$ Seah et al., State of Southeast Asia, 33.

${ }^{103}$ Seah et al., State of Southeast Asia, 33.

${ }^{104}$ Seah et al., State of Southeast Asia, 33.
} 
One should also look at certain trends - e.g. the ease with which political systems in Southeast Asia reduce liberal political rights due to the pandemic as actually strengthening possible cooperation with China. ${ }^{105}$ The presidency of Joe Biden has been welcomed in Southeast Asia, raising hopes of a less confrontational approach by the US towards China. ${ }^{106}$ Rebuilding the US's position in Southeast Asia, with a special focus on key players, seems to be an important task for Biden's administration, as it was neglected by the Trump administration, hence China could reinforce its position. ${ }^{107}$

China is perceived as a key economic and political actor in Southeast Asia, and can be considered a growing military power in the region due to increasing fears of its military presence in the South China Sea. However, in terms of military power, China has yet to overtake the US as the leading power in the region. While Covid-19 increased the view of China as the main strategic partner for dealing with the pandemic, China has not been successful in replacing the US in other areas of engagement. In the areas where China has increased its influence, the election of Joe Biden has returned the US to a much stronger position. It is clear that in Southeast Asia, the US maintains its position as the dominant nation.

\section{CONCLUSION}

China has benefited from the current international system and can be understood under the power transition theory to be satisfied with the system. China benefits from the current system of global governance, and it is within its best interests to maintain it. However, the Trump administration's retreat from important international treaties and organisations and its attempt to undermine the Obama administration's new institutional architecture in Asia have created a situation where maintaining the current systems of global and regional governance was not possible for China.

The failure of the US to lead the global response to Covid-19 created a power vacuum in global and regional governance. In Southeast Asia, China attempted to fill that vacuum with mask and vaccination diplomacy. During the Covid-19 pandemic, China has moved from a satisfied state to an aspiring power, and is challenging the US's position as a dominant nation, at least at a regional level. However, has Hypothesis 1-Covid-19 accelerated China's rise to power, causing a decline in the US's relative position in Southeast Asia-been proved? Both the lack of effectiveness of China's medical diplomacy and the fact that

\footnotetext{
${ }^{105}$ Joshua Kurlantzick, 'The pandemic and Southeast Asia's democratic struggles', Current History 119 (818) (2020), 228-33.

${ }^{106}$ Malcolm Cook and Ian Storey, 'The impending Biden presidency and Southeast Asia', ISEAS Perspective 143 (2020).

${ }^{107}$ Yohanes Sulaiman, Mariane Delanova and Rama Daru Jati, 'Indonesia between the United States and China in a post-Covid-19 world order', Asia Policy 16 (1) (2021), 155-78.
} 
policymakers in Southeast Asia, following the election of Biden, are once again looking toward the US for leadership suggest that CoviD-19 as an external shock had only a short-term effect on China's position relative to the US's.

Reacting to China's rise, the US has introduced policies to maintain its global position. The Obama administration's Asia Pivot planned to build new institutional architecture in Asia by fostering middle power allegiance and by increasing its relative military and regulatory capabilities in the region. In many ways, the Trump administration continued Obama's strategy to limit Chinese influence, particularly in the Asian region. However, the Trump administration's approach preferred bilateral agreements, middle power allegiance and a withdrawal from the international system, which led to a more confrontational approach to China, as the Sino-American trade war illustrated.

The external shock of the Covid-19 pandemic and the Trump administration's withdrawal from regional agreements (such as the TPP) and global bodies (such as the WHO) opened a vacuum of leadership at global and regional levels in Asia. An absence of US leadership, both regionally and globally, became clear when Covid-19 was declared a pandemic. In Southeast Asia, policymakers looked to China rather than to the US for assistance and leadership during the pandemic. However, it is unclear whether the pandemic itself increased China's power or it acted as a catalyst for China's rise to power.

The Biden administration's return to Obama's approach of containing China's rise suggests that any power transition due to the Covid-19 pandemic is a short-term phenomenon. This would suggest that the alternative Hypothesis 2 - Covid-19 has not affected the US's dominant regional position-is proved. It is clear that, during the pandemic, the US has maintained its dominant global position through the allegiance of a network of middle powers and has retained its regulatory position due to its long-term leadership in global and regional governance.

The Trump administration's withdrawal from US-led global and regional governance during the early period of Covid-19 created a power vacuum, allowing China to adopt a leadership role. The short-term adoption of China as the dominant nation in the Southeast Asia region due the Covid-19 pandemic highlights that China has the capability and willingness to take the lead in response to external shocks when the US is unable or unwilling to do so. The case of Southeast Asia also suggests that policy-makers within the middle powers that show allegiance to the US are willing to turn to China for leadership in regard to external shocks when the US is unable or unwilling to do so. This suggests that the US's capability to maintain a network of allegiance and a system of institutions that underpin its power may be weaker than is currently considered. 